\title{
A p.P30L MUTATION AT THE CYP21A2 GENE IN MACEDONIAN PATIENTS WITH NONCLASSICAL CONGENITAL ADRENAL HYPERPLASIA
}

\author{
Anastasovska $\mathrm{V}^{1}$, Kocova $\mathrm{E}^{1}$, Kocova $\mathrm{M}^{1,2, *}$
}

*Corresponding Author: Mirjana Kocova, University Children's Clinic, Department of Endocrinology and Genetics, Vodnjanska 17, 1000 Skopje, Macedonia; Tel.: +38-970-242-694; Fax: +38-923-176-167; E-mail: mirjanakocova@yahoo.com

\begin{abstract}
Nonclassical congenital adrenal hyperplasia (NCAH) is an autosomal recessive imbalance in cortisol synthesis with adrenal androgen excess. Although rarely recognized in infants, it may cause premature adrenarche and pubarche, virilization in young women and variable symptoms in young men. It is commonly caused by mutations in CYP21A2, the gene for steroid 21-hydroxylase. Patients with the p.P30L allele tend to have pronounced evidence of androgen excess but are categorized as nonclassical. We used direct molecular detection of the p.P30L mutation in CYP21A2 in 11 Macedonian NCAH patients and in 17 members of their families using polymerase chain reaction/amplification created restriction site (PCR/ACRS) analysis and digestion with restriction enzymes. The p.P30L mutation was found in a homozygous state in seven $(63.6 \%)$ and in a heterozygous state in four $(36.4 \%)$ patients. Of the latter, one was also heterozygous for the p.Q318X mutation. The p.P30L mutation

1 Genetics Laboratory, University Children's Clinic, Skopje, Republic of Macedonia

2 Department of Endocrinology and Genetics, University Children's Clinic, Skopje, Republic of Macedonia
\end{abstract}

was found in a heterozygous state in $10(58.8 \%)$ and in a homozygous state in one $(5.9 \%)$ of the family members. These findings support a role of the p.P30L mutation in NCAH.

Key words: CYP21A2 gene, 21-Hydroxylase deficiency, Nonclassical congenital adrenal hyperplasia (NCAH), p.P30L Mutation

\section{INTRODUCTION}

Nonclassical congenital adrenal hyperplasia (NCAH), an autosomal recessive disease, affects about 1 in 30 Ashkenazi Jews and 1 in 1,000 non Jewish Caucasians of mixed ethnicity [1]. It is commonly due to a mutation in the CYP21A2, a gene for steroid 21-hydroxylase [2]. Impaired enzyme activity (20-50\% of wild type enzymatic action) leads to adrenal androgen excess. Unlike more severe forms of congenital adrenal hyperplasia $(\mathrm{CAH}), \mathrm{NCAH}$ is rarely recognized in infants but may lead to premature adrenarche and pubarche, virilization in young women, and variable symptoms in young men [3]. Typically, infant girls do not have genital ambiguity but those who carry combinations of mild and severe mutant CYP21A2 alleles may have mild clitoromegaly or a partial urogenital sinus. In adolescence, females are more seriously affected than males, and may develop distressing 
features of androgen excess, such as hirsutism and acne. Oligomenorrhea, which is rare in adolescence, may be more severe in NCAH. Reproductive problems are also more common in NCAH women than in the general population [4]. Although there is no gender predilection for $\mathrm{CAH}$, males are not readily detected with androgen excess after childhood. Oligospermia and infertility have been described, but less often than in classic CAH $[5,6]$. Differentiation of 21-hydroxylase deficiency from other enzyme defects is determined by the ACTHstimulation test, which in patients with $\mathrm{NCAH}$, raises serum levels of 17-hydroxyprogesterone (17OH-P) to $50-300 \mathrm{nmol} / \mathrm{L}$ [7].

The CYP21A2 gene is located on $6 \mathrm{p} 21.3$, within the class III region of the highly polymorphic HLA histocompatibility complex [8], with the pseudogene (CYP21A1P), with which it shares 98\% homology in the exonic sequences. CYP21A2 consists of $3.2 \mathrm{~kb}$ pairs and contains 10 exons [9]. It is highly polymorphic, more than 100 alleles having been identified in patients and families with severe, moderate and mild forms of $\mathrm{CAH}$ $[10,11]$. Few alleles are specifically associated with NCAH. Most commonly, late-onset 21-hydroxylase deficiency results from a homozygous conservative point mutation p.V281L, p.P30L, and p.P453S [12]. We used direct molecular detection of the p.P30L mutation in CYP21A2 in 11 Macedonian patients with $\mathrm{NCAH}$ and in an equal number of their relatives.

\section{MATERIALS AND METHODS}

Nine unrelated girls and two boys with $\mathrm{NCAH}$ and 17 of their parents or relatives were studied. Diagnosis was made at age 4 to16 $(8.5 \pm 3.6)$ years at the Department of Endocrinology and Genetics, University Children's Hospital, Skopje, Republic of Macedonia. The presenting signs were: premature pubarche/adrenarche, hirsutism and/or oligoamenorrhea, and diagnosis of $\mathrm{NCAH}$ was based on these and on advanced bone age, abnormally elevated ACTH-stimulated 17OH-P serum levels and molecular gene analysis.

The samples were screened for the $\mathrm{pP} 30 \mathrm{~L}$ mutation. The samples heterozygous for $\mathrm{pP} 30 \mathrm{~L}$ or non carriers for this mutation were also tested for 10 other different mutations (IVS-II-655 C/A $>\mathrm{G}, 8$ bp frameshift deletion at codons 111-113, p.I172N, p.I236N, p.V237E, p.M239K, p.V281L, p.F306+T, p.Q318X and p.R356W) according to the polymerase chain reaction/amplification created restriction site (PCR/ACRS), method. Thus, $90 \%$ of all the mutations identified in CAH patients were covered $[13,14]$.

Molecular Analysis. Genomic DNA was extracted from peripheral blood lymphocytes following the standard phenol/chloroform protocol [15]. The primary differential PCR amplification of the active CYP21A2 gene, without contamination from the highly homologous pseudogene sequence, was performed with 20 pmol of each CYP21A2 (21BF/21BR) specific primer (21BF: 5'-TCG GTG GGA GGG TAC CTG AAG-3' and 21BR: 5'-AAT TAA GCC TCA ATC CTC TGC AGC G-3') in a final volume of $100 \mu \mathrm{L}$ containing $1 \mu \mathrm{g}$ of genomic DNA, $200 \mu \mathrm{M}$ of each dNTP, $1.5 \mathrm{mM} \mathrm{Mg}(\mathrm{OAc})_{2}$ and $4 \mathrm{U}$ rTth DNA polymerase, XL (GeneAmp XL PCR kit; Applied Biosystems, Branchburg, NJ, USA). The EcoRI digestion of the $3.2 \mathrm{~kb}$ PCR active gene product, with two fragments $(1.0$ and $2.2 \mathrm{~kb})$ as an end result, ensured that only the gene sequence had been amplified and analyzed (Figure 1).

The primary PCR product was then used as a template for secondary PCR amplification using ACRS with a pair of primers specific for direct mutational detection of p.P30L mutation $(\mathrm{C} 1 \mathrm{~N}$ : 5'CTA CAC AGC AGG AGG GAT GGC-3' and C2: 5'-AGC AAG TGC AAG AAG CCC GGG GCA AGc tG-3'). The secondary ACRS PCR was carried out in a final volume of $50 \mu \mathrm{L}$, containing primary PCR product, $50 \mathrm{pmol}$ of each primer, $200 \mu \mathrm{M}$ of

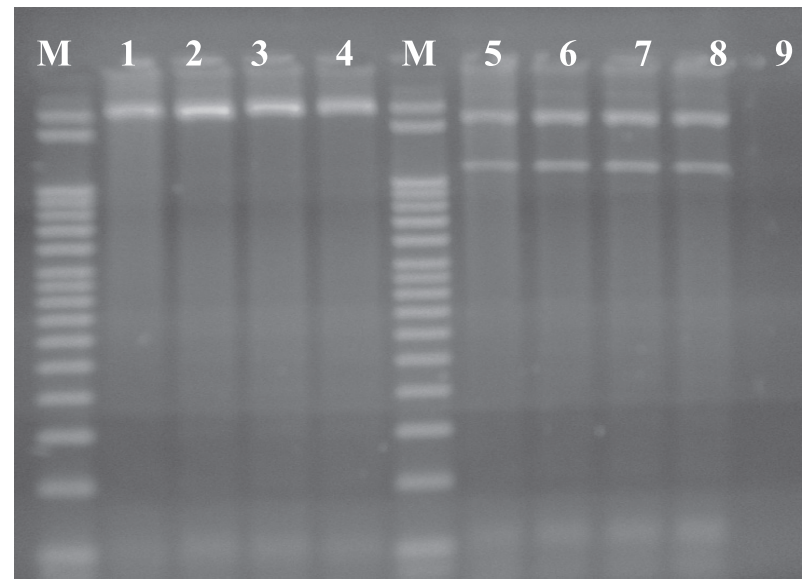

Figure 1. A $3.2 \mathrm{~kb}$ PCR product of CYP21A2 (lanes 1-4) and EcoRI digestion of CYP21A2 gene (lanes 5-8); lane 9: blank, M: marker (50 bp). 


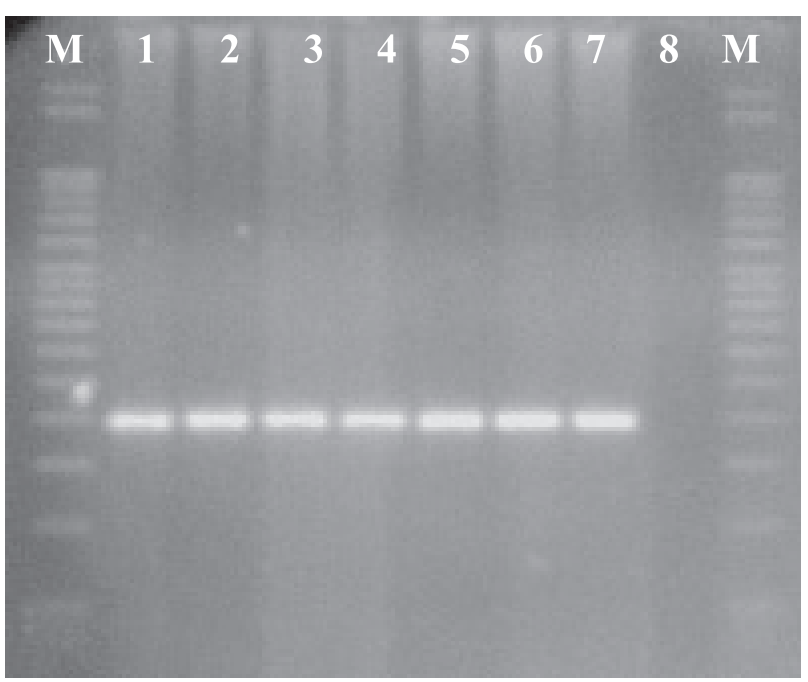

Figure 2. A 195 bp PCR product of ACRS/PCR mutational analysis on exon 1 of CYP21A2 gene (lanes 1-7), lane 8: blank, M: marker (50 bp).

each dNTP, $1.5 \mathrm{mM} \mathrm{MgCl}$ and $1.25 \mathrm{U}$ Taq DNA polymerase (Ampli Taq Gold; Applied Biosystems). A 195 bp PCR product was obtained (Figure 2). The amplified fragments were digested with 5-10 U of a PstI restriction enzyme at $37^{\circ} \mathrm{C}$ overnight. The digestion products were run on $2 \%$ high resolution agarose gel and visualized under UV light after ethidium bromide staining.

The identification was based on presence of a recognition site for the restriction enzyme PstI. Region specific primers create a PstI restriction site in the mutant allele at codon 30 which yields two fragments (164 and $31 \mathrm{bp}$ ). In the normal allele there is no restriction site for PstI (Figure 3). Subsequent restriction analysis also allowed determination of the zygosity of the mutation.

\section{RESULTS AND DISCUSSION}

Premature pubarche/adrenarche was present in six girls, hirsutism and oligoamenorrhea in two, and amenorrhea in one. The boys presented with adrenarche, typical development of genitalia, and increased rate of growth. Bone age was advanced by $3.6 \pm 1.2$ years (range: 1 to 4.5 ). The peak of ACTH-stimulated $17 \mathrm{OH}-\mathrm{P}$ serum level was higher than $60 \mathrm{nmol} / \mathrm{L}$ in all patients.

The p.P30L mutation was detected in all NCAH patients: seven patients $(63.6 \%)$ were homozygous (five girls and two boys) and four girls (36.4\%) were heterozygous. One of the heterozygous patients was also heterozygous for a p.Q318X mutation, as previously reported [14].

Patients with the p.P30L allele, although still categorized as nonclassical, tend to have pronounced evidence of androgen excess [16]. A genotype that contains two mild mutant alleles produces clinical symptoms of $\mathrm{NCAH}$, the allele that produces most enzyme activity determining the phenotype $[17,18]$. Thus, the patient who was heterozygous for p.P30L and p.Q318X presented with a nonclassical phenotype. However, women who have NCAH may give birth to children with a classical form of the disease if the father is heterozygous for a severe mutation. Prenatal diagnosis in the case of such a combination of parents is strongly recommended. However, the correlation of genotype to phenotype that we found in all of our NCAH patients strengthens the concept that the genotype is predictive of phenotype.

Besides the p.P30L mutation which was derived from pseudogene, mutations not found in the pseudogene, p.R339H, p.P453S [19], and p.H62L $[20,21]$ are also associated with partially impaired in vitro activity of 21-hydroxylase but together probably account for no more than $5 \%$ of $\mathrm{NCAH}$ alleles $[22,23]$. The p.P30L mutation was found in $11 / 17$ of the family members $(64.7 \%), 10$ were

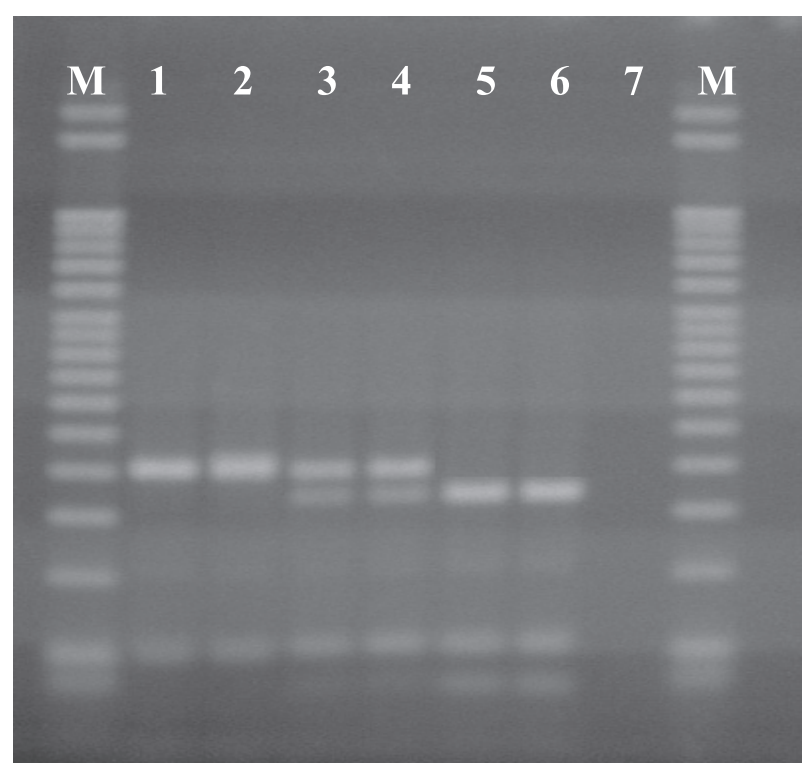

Figure 3. Digestion with Pst $\mathrm{I}$ restriction enzyme, lanes 1 and 2: normal (195 bp); lanes 3 and 4: heterozygous (195 bp/164+31 bp); lanes 5 and 6: homozygous (164+31 bp); lane 7: blank, M: marker (50 bp). 
heterozygotes $(58.8 \%)$ and one was a homozygote (5.9\%). Only the mother (homozygous for p.P30L) and father (homozygous for p.Q318X) of the compound heterozygous patient, as previously reported, had infertility and oligospermia, respectively [18].

The previously reported genetic analysis confirmed a significant genotype to phenotype correlation and a prevalence of NCAH of 1:7000 in the Macedonian population [24,25]. Although p.P30L is classified as a mild mutation in CYP21A2, its role in increased virilization remains to be elucidated.

\section{REFERENCES}

1. Speiser PW, Dupont B, Rubinstein P, Piazza A, Kastelan A. New MI. High frequency of nonclassical steroid 21-hydroxylase deficiency. Am J Hum Genet 1985; 37(4): 650-670.

2. White PC, Speiser PW. Congenital adrenal hyperplasia due to 21-hydroxylase deficiency. Endocr Rev 2000; 21(3): 245-291.

3. Rosha RO, Billerbeck AEC, Pinto EM, Melo KFS, Lin CJ, Longui CA, Mendoca BB, Bachega TASS. The degree of external genitalia virilization in girls with 21-hydroxylase deficiency appears to be influenced by the CAG repeats in the androgen receptor gene. Clin Endocrinol 2008; 68(2): 226232.

4. Azziz R, Sanchez LA, Knochenhauer ES, Moran C, Lazenby J, Stephens KC, Taylor K, Boots LR. Androgen excess in women: experience with over 1000 consecutive patients. J Clin Endocrinol Metab 2004; 89(2): 453-462.

5. Augarten A, Weissenberg R, Pariente C, Sack $\mathrm{J}$. Reversible male infertility in late onset congenital adrenal hyperplasia. J Endocrinol Invest 1991; 14(3): 237-240.

6. Kalachanis I, Rousso D, Kourtis A, Goutzioulis F, Makedos G, Panidis D. Reversible infertility, pharmaceutical and spontaneous, in a male with late onset congenital adrenal hyperplasia, due to 21-hydroxylase deficiency. Arch Androl 2002; 48(1): 37-41.

7. New MI, Lorenzen F, Lerner AJ, Kohn B, Oberfield SE, Pollack MS, Dupont B, Stoner E, Levy DJ, Pang S, Levine LS. Genotyping steroid 21-hydroxylase deficiency: hormonal reference data. J Endocrinol Metab. 1983; 57(2): 320-326.
8. Speiser PW, White PC. Congenital adrenal hyperplasia. N Engl J Med 2003; 349(8): 776-788.

9. White PC, New MI, Dupont B. Structure of the human steroid 21-hydroxylase gene. Proc Natl Acad Sci USA 1986; 83(24): 5111-5115.

10. White PC, Tusie-Luna MT, New MI, Speiser PW. Mutations in steroid 21-hydroxylase (CYP21). Hum Mutat 1994; 3(3): 373-378.

11. The Human Gene Mutation Database at the Institute of Medical Genetics in Cardiff (http:// www.hgmdc facuk/ac/index.php).

12. Speiser PW, New MI, While PC. Molecular genetic analysis of nonclassic steroid 21-hydroxylase deficiency associated with HLA-B14,DR1. N Engl J Med 1988; 319(1): 19-23.

13. Lee HH, Chao HT, Ng HT, Choo KB. Direct molecular diagnosis of CYP21 mutations in congenital adrenal hyperplasia. J Med Genet 1996; 33(5): 371-375.

14. Anastasovska V, Kocova M. Molecular analysis of family with congenital adrenal hyperplasia-genotype/phenotype discrepancy. Balkan J Med Genet 2007; 10(2): 23-27.

15. Efremov GD, Dimovski AJ, PlaseskaKaranfilska D, Simjanovska L, Sukarova E, Koceva S. Laboratory Manual, 3rd ed. Skopje: ICGEB Affiliated Center, Nucleic Acid Based Methods in Human and Veterinary Medicine, 1999.

16. Tusie-Luna MT, Speiser PW, Dumic M, New MI, White PC. A mutation (Pro-30 to Leu) in CYP21 represents a potential nonclassic steroid 21-hydroxylase deficiency allele. Mol Endocrinol 1991; 5(5): 685-692.

17. Speiser PW, Dupont J, Zhu D, Serrat J, Buegeleisen M, Tusie-Luna MT, Lesser M, New MI, White PC. Disease expression and molecular genotype in congenital adrenal hyperplasia due to 21-hydroxylase deficiency. J Clin Invest 1992; 90(2): 584-595.

18. Dolžan V, Sólyom J, Fekete G, Kovács J, Rakosnikova V, Voltava F, Lebl J, Pribilincova Z, Baumgartner-Parzer SM, Riedl S, Waldhauser F, Frish H, Stopar-Obreza M, Kržišnik C, Battelino T. Mutational spectrum of steroid 21-hydroxylase and the genotype-phenotype association in the Middle European patients with congenital adrenal hyperplasia. Eur J Endocrinol 2005; 153(1): 99-106.

19. Helmberg A, Tusie-Luna MT, Tabarelli M, Kofler R, White PC. R339H and P453S: CYP21 
mutations associated with nonclassic steroid 21-hydroxylase deficiency that are not apparent gene conversions. Mol Endocrinol 1992; 6(8): 1318-1322.

20. Menassa R, Tardy V, Despert F, BouvattierMorel C, Brossier JP, Cartigny M, Morel Y. p.H62L, a rare mutation of the CYP21 gene identified in two forms of 21-hydroxylase deficiency. J Clin EndocrinoL Metab 2008; 93(5): 1901-1908.

21. Soardi FC, Barbaro M, Lau IF, LemosMarini SH, Baptista MT, Guerra-Junior G, Wedell A, Lajic S, De Mello MP. Inhibition of CYP21A2 enzyme activity caused by novel missense mutations identified in Brazilian and Scandinavian patients. J Clin Endocrinol Metab 2008; 93(6): 2416-2420.

22. Balsamo A, Cacciari E, Baldazzi L, Tartaglia L, Cassio A, Mantovani V, Piazzi S, Cicognani A, Pirazzoli P, Mainetti B, Zappulla F. CYP21 analysis and phenotype/genotype relationship in the screened population of the
Italian Emilia-Romagna region. Clin Endocrinol 2000; 53(1): 117-125.

23. Dolžan V, Stopar-Obreza M, Žerjav-Tanšek M, Breskvar K, Kržišnik C, Battelino T. Mutational spectrum of congenital adrenal hyperplasia in Slovenian patients: a novel Ala15Thr mutation and Pro30Leu within a larger gene conversion associated with a severe form of the disease. Eur J Endocrinol 2003; 149(2): 137-144.

24. Kocova M, Krstevska-Konstantinova M, Conevska B. Congenital adrenal hyperplasia in the Republic of Macedonia. 4th Asian Symposium of Childhood and Juvenile Endocrinology and Diabetes, January 26-29 1997, Chiang Mai, Thailand. Book of Abstracts, 68 .

25. Kocova M, Sigel S, Krstevska-Konstantinova M, Blagoevska M, Trucco M. Detection of CYP21B gene mutation in the Republic of Macedonia. 8th Balkan Congress of Endocrinology, May 3-5, 1995, Bursa, Turkey. Book of Abstracts, 66. 
